\title{
Enterocarpam-III Induces Human Liver and Breast Cancer Cell Apoptosis via Mitochondrial and Caspase-9 Activation
}

\author{
Ratana Banjerdpongchai ${ }^{1 *}$, Benjawan Wudtiwai ${ }^{1}$, Wilart Pompimon ${ }^{2}$
}

\begin{abstract}
An aristolactam-type alkaloid, isolated from Orophea enterocarpa, is enterocarpam-III (10-amino-2,3,4,6tetramethoxyphenanthrene-1-carboxylic acid lactam). It is cytotoxic to various human and murine cancer cell lines; however, the molecular mechanisms remain unclear. The aims of this study were to investigate cytotoxic effects on and mechanism (s) of human cancer cell death in human hepatocellular carcinoma HepG2 and human invasive breast cancer MDA-MB-231 cells compared to normal murine fibroblast NIH3T3 cells. Cell viability was determined by MTT assay to determine $\mathrm{IC}_{10}, \mathrm{IC}_{20}$ and $\mathrm{IC}_{50}$ levels, reactive oxygen species (ROS) production with 2',7'-dichlorohydrofluorescein diacetate and the caspase-3, -8 and -9 activities using specific chromogenic (p-nitroaniline) tetrapeptide substrates, viz., DEVD-NA, IETD-NA and LEHD-NA and employing a microplate reader. Mitochondrial transmembrane potential (MTP) was measured by staining with 3, 3'-dihexyloxacarbocyanine iodide $\left(\mathrm{DiOC}_{6}\right.$ ) and using flow cytometry. The compound was cytotoxic to HepG2 and MDA-MB-231 cells with the $\mathrm{IC}_{50}$ levels of $26.0 \pm 4.45$ and $51.3 \pm 2.05 \mu \mathrm{M}$, respectively. For murine normal fibroblast $\mathrm{NIH} 3 \mathrm{~T} 3$ cells, the $\mathrm{IC}_{50}$ concentration was $81.3 \pm 10.1 \mu \mathrm{M}$. ROS production was reduced in a dose-response manner in HepG2 cells. The caspase-9 and -3 activities increased in a concentration-dependent manner, whereas caspase-8 activity did not alter, indicating the intrinsic pathway activation. Enterocarpam-III decreased the mitochondrial transmembrane potential (MTP) dose-dependently in HepG2 cells, suggesting that the compound induced HepG2 cell apoptosis via the mitochondrial pathway. In conclusion, enterocarpam-III inhibited HepG2 and MDA-MB-231 cell proliferation and induced human HepG2 cells to undergo apoptosis via the intrinsic (mitochondrial) pathway and induction of caspase-9 activity.
\end{abstract}

Keywords: Enterocarpam-III - Orophea enterocarpa - apoptosis - HepG2 cells - MDA-MB-231 cells - mitochondria

Asian Pac J Cancer Prev, 16 (5), 1833-1837

\section{Introduction}

There has been a report of enterocarpam-I and -II isolated from Orophea enterocarpa (Kamaliah et al., 1986). The structure of enterocarpam-I (10-amino-3hydroxy-4,8,9-trimethoxyphenanthrene-1-carboxylic acid lactam) and enterocarpam-II (10-amino-3-hydroxy-4,8dimethoxyphenanthrene-1-carboxylic acid lactam) are different from that of enterocarpam-III (10-amino-2, 3, 4, 6-tetramethoxyphenanthrene-1-carboxylic acid lactam). Their core structures are classified as aristolactam-type alkaloids. Orophea enterocarpa is in Annonaceae plant family.

Two alkaloids from Pseuduvaria rugosa (Blume) Merr. (Annonacaea) are isolated and identified as 1,2,3-trimethoxy-5-oxonoraporphine and ouregidione. Both ouregidione and 1,2,3-trimethoxy-5oxonoraporphine induce cytotoxicity against human leukemic HL-60, U937, and K562 cells whereas 1, 2, 3 -trimethoxy-5-oxonoraporphine is more active than ouregidione. Both compounds increase significantly the proportion of the cells in $\mathrm{S}$ phase, whereas 1,2 , 3-trimethoxy-5-oxonoraporphine induces HL-60 cell line arrest in G2/M and ouregidione does the G1 phase arrest (Uadkla et al., 2013).

Alkaloids from Chinese medicinal plant Tripterygium hypoglaucum (levl.) Hutch (Celastraceae) (THH) roots are tested for cytotoxicity against HL-60 and determined for the molecular mechanism involved in the induction of HL60 cell apoptosis by employing cDNA microarrays derived from a human leukocyte cDNA library. Sixteen genes are demonstrated to be significantly and differentially expressed in HL-60 cells upon THH treatment. Various genes relate to the NF- $x \mathrm{~B}$ signaling pathway, such as nuclear factor of kappa light polypeptide gene enhance in B-cells inhibitor, beta (NFKBIB); proteoglycan 1, secretory granule (PRG1); and beta-2-microglobulin (B2M) are up-regulated. Moreover, c-myc binding protein and apoptosis-related cysteine proteases caspase- 3 and caspase- 8 are also significantly regulated. Conclusively, 
THH alkaloid mixture can induce HL-60 cell apoptosis via c-myc and NF- $x \mathrm{~B}$ signaling pathways (Zhuang et al., 2004).

Tylophora alkaloids (from Tylophora indica), which are herb products containing anti-asthamatic and antiproliferative activities. These alkaloids induce human erythroleukemic K562 cell apoptosis with characteristic apoptosis morphologies, viz., nuclear condensation, apoptotic body formation, externalization of phosphatidylserine in cell membrane, caspase- 3 activation and mitochondrial cytochrome c release into cytosol. Hence, Tylophora alkaloids could be useful agents for the antiproliferative activity and for induction of apoptosis in human leukemic cells and cancer cells (Ganguly and Khar, 2002).

Pyrrolizidine alkaloids are classified as natural hepatotoxins with the distribution in more than 6,000 herbs including medicinal herbs and teas worldwide. Clivorine, isolated from Ligularia hodgsonii Hook, decreases cell viability and induces apoptosis in human embryo liver L-02 cells and mouse hepatocytes. Clivorine induces caspase- 3 and -9 activation, mitochondrial cytochrome c release and decreases anti-apoptotic $\mathrm{Bcl}-\mathrm{xL}$ protein level. Polyubiquitination of $\mathrm{Bcl}-\mathrm{xL}$ after incubation with $100 \mu \mathrm{M}$ clivorine for $40 \mathrm{~h}$ in the presence of proteasome specific inhibitor MG132 is present, indicating possible degradation of Bcl-xL protein. Another alkaloid hepatotoxin, i.e., senecionine, isolated from Senecio vulgaris L. also induces mouse hepatocyte apoptosis via caspase- 3 activation and decreases Bcl-xL level. It is suggested that pyrrolizidine alkaloids activate hepatotoxic signaling pathway involving degradation of Bcl-xL protein and activation of mitochondria-mediated apoptotic pathway (Ji et al., 2008).

Enterocarpam-III contains the anti-cancer activity against human colon adenocarcinoma HCT15 cell line (Nayyatip et al., 2012). However, the mode and mechanism of cancer cell death remain unclear. The aims of this study were to identify its cytotoxic effect and mechanistic pathway of cancer cell death on human hepatocellular carcinoma HepG2 and human breast cancer MDA-MB-231 cells compared with normal murine fibroblast NIH3T3 cells as models for the study.

\section{Materials and Methods}

\section{Materials}

Leibovitz's L-15 Medium, Dulbecco's Modified Eagle Medium (DMEM), fetal bovine serum, streptomycin and penicillin $\mathrm{G}$ sodium were obtained from Gibco BRL, Thermo Fisher Scientific Inc., Waltham, MA, USA. Dimethyl sulfoxide (DMSO), 3, 3'-dihexyloxacarbocyanine iodide ( DiOC $\left._{6}\right)$, 2', 7'dichlorohydrofluorescein diacetate (DCFH-DA) and 3-(4, 5-dimethyl)-2, 5-diphenyltetrazolium bromide (MTT) dye were obtained from Sigma/Aldrich, St. Louis, MO, USA. The substrates of caspase-9 (LEHD-7-para-nitroaniline, LEHD-p-NA), caspase-8 (IETD- p-NA) and caspase-3 (DEVD- p-NA) were obtained from Invitrogen, Thermo Fisher Scientific Inc., Waltham, MA, USA.

\section{Isolation and extraction}

The compound was isolated from air-dried twigs and leaves of $O$. enterocarpa, which was collected in March 2009 from Prajean Buri Province in Thailand. The plant was identified by N. Nuntasaen and a voucher specimen BKF no. 151499 was deposited at the Forest Herbarium, Department of National Park, Wildlife and Plant Conservation, Ministry of National Resources and Environment, Bangkok, Thailand.

The ground dried powder of leaves and twigs of the plant was successively extracted with various solvents, beginning with hexane and then methanoldichloromethane $(3: 1)$. Each solvent was removed from the extract under reduced pressure. The methanoldichloromethane extract was further separated by column chromatography over silica gel using gradient elution. Initially n-hexane was conducted and then gradually enriched with ethyl acetate, followed by increasing amount of methanol in ethyl acetate and finally with methanol to afford eleven fractions, F1-F11. Fraction F4 was rechromatographed over silica gel with gradient system between hexane, ethyl acetate and methanol to give five subfractions, A1-A5. The pale yellow precipitate in subfraction A4 was recrystallized from ethanol to obtain entercarpam-III with the yield $0.01 \%$ and the structure is shown in Figure 1. The structure was proved by mass spectrometry and NMR. The protocol of purification and characterization was followed that of Nayyatip and his colleagues (Nayyatip et al., 2012).

\section{Cell lines}

Human hepatocellular carcinoma HepG2 and human invasive breast cancer MDA-MB-231 cells were obtained from Associate Professor Dr. Prachya Kongtawelert, at Excellence Center of Tissue Engineering and Stem Cells, Department of Biochemistry, Faculty of Medicine, Chiang Mai University. Murine normal fibroblast NIH3T3 cells were obtained from Professor Dr. Usanee Vinitketkumneun at Department of Biochemistry, Faculty

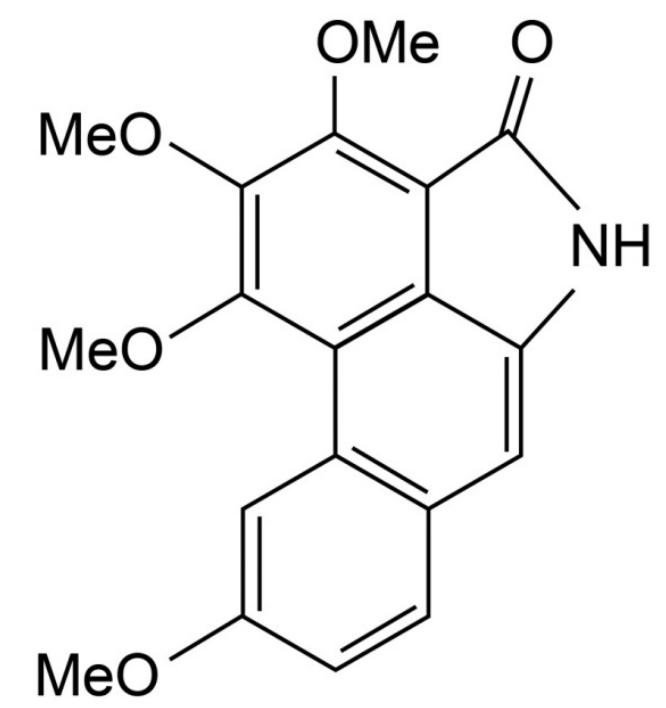

Figure 1. Chemical Structure of Enterocarpam-III. (10-amino-2,3,4,6-tetramethoxyphenanthrene-1-carboxylic acid lactam) 
of Medicine, Chiang Mai University. MDA-MB-231 cells were cultured in Leibovitz's L-15 Medium whereas HepG2 and NIH3T3 cells were cultured in DMEM with $25 \mathrm{mM} \mathrm{NaHCO}, 20 \mathrm{mM}$ HEPES, 100 units/ml penicillin, $100 \mu \mathrm{g} / \mathrm{ml}$ streptomycin and supplement with $10 \%$ fetal bovine serum.

\section{Cytotoxicity test}

HepG2 and MDA-MB-231 cells ( $5 \times 10^{5}$ cells $\left./ \mathrm{ml}\right)$ were treated with the compound at various concentrations for 24 hours. The cell viability was determined by MTT assay (Banjerdpongchai et al., 2013b). Briefly, MTT dye was added to cell suspension at the final concentration of $100 \mu \mathrm{g} / \mathrm{ml}$ and incubated for $4 \mathrm{~h}$ in a humidified $5 \% \mathrm{CO}_{2}$ atmosphere. The medium was removed and the crystal was dissolved with dimethyl sulfoxide for $30 \mathrm{~min}$. The absorbance was determined at $540 \mathrm{~nm}$ with the reference wavelength of $630 \mathrm{~nm}$ using microplate reader (Biotek, Winooski, VT, USA). The inhibitory concentrations at 10,20 and $50 \%$ were determined to apply for further experiments.

\section{Determination of ROS production}

HepG2 cells were treated with enterocarpam-III at $\mathrm{IC}_{10}, \mathrm{IC}_{20}$ and $\mathrm{IC}_{50}$ for $4 \mathrm{~h}$ and then washed with phosphate buffered-saline before 2',7'-dichlorohydrofluorescein diacetate was added to the final concentration of $5 \mu \mathrm{M}$. The fluorescence intensity was measured by fluorescence microplate reader (Biotek, Winooski, VT, USA) (Wudtiwai et al., 2011).

\section{Determination of caspase-3, -8 and -9 activities}

After HepG2 cells were incubated with the enterolactam-III at various concentrations for $24 \mathrm{~h}$, the chromogenic substrate of each caspase, i.e., Leu-GluHis-Asp- p-NA (LEHD-p-NA), Ile-Glu-Thr-Asp (IETDp-NA) and Asp-Glu-Val-Asp-p-NA (DEVD-p-NA), was added to the reaction buffer of the cell lysate. The mixture was incubated for an hour and the caspase- $9,-8$ and -3 activities were measured as their absorbance by using microplate reader (Biotek, Winooski, VT, USA) (Banjerdpongchai et al., 2013a).

\section{Measurement for mitochondrial transmembrane potential (MTP)}

HepG2 cells were incubated with the compounds at the concentrations of $\mathrm{IC}_{10}, \mathrm{IC}_{20}$ and $\mathrm{IC}_{50}$, then $\mathrm{DiOC}_{6}$ was added to the final concentration of $40 \mathrm{nM}$. The fluorescence intensity of each condition was determined

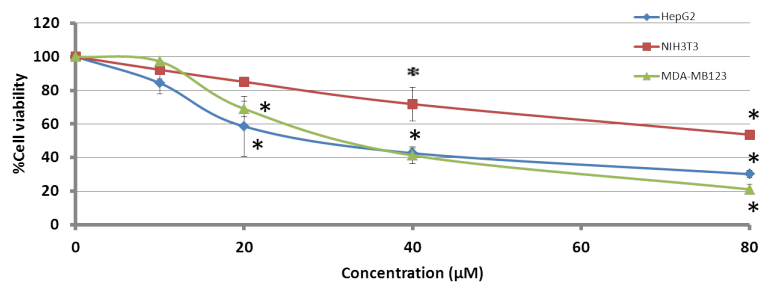

Figure 2. Cytotoxicity of Enterocarpam-III Towards HepG2, MDA-MB-231 and NIH3T3 Cell Lines. Percent cell viability is shown as mean \pm S.D. $* \mathrm{p}<0.05$ compared to control
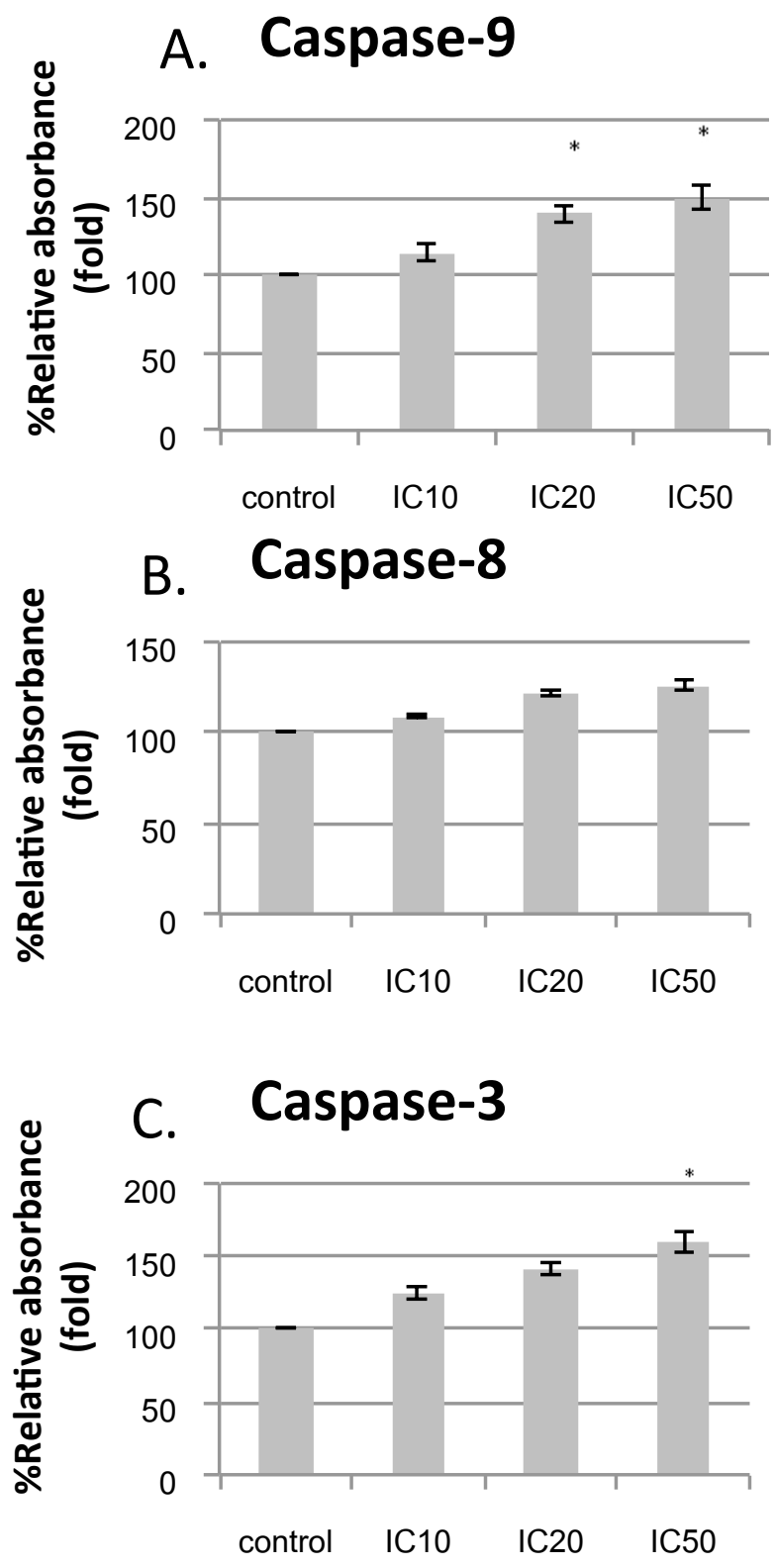

Figure 4. Caspase-3, -8 and -9 Activities of HepG2 Cells after Treatment with Enterocarpam-III for 24 Hours. Percent relative p-NA absorbance is shown as mean \pm S.D., representing activities of aspase- 9 (A), -8 (B) and -3 (C) activities. *, p $<0.05$ compared to control

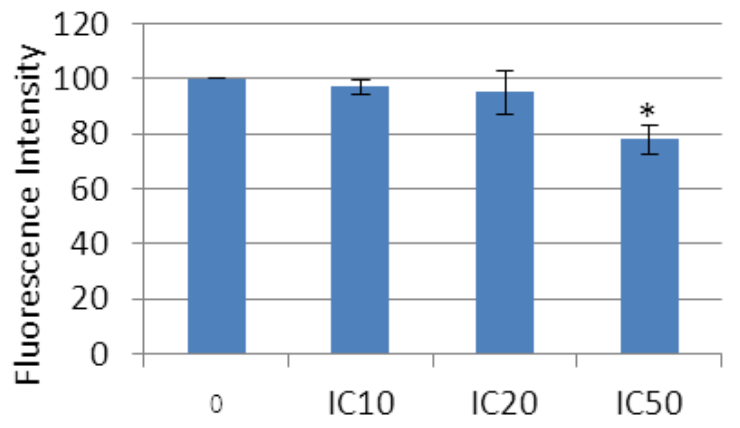

Figure 3. Reactive Oxygen Species (ROS) Production of HepG2 Cells when Incubated with Enterocarpam-III for 4 Hours. ROS production decreased as the enterocarpam-III dosage increased, which was measured as described in Methods. $* \mathrm{p}<0.05$ compared to control 


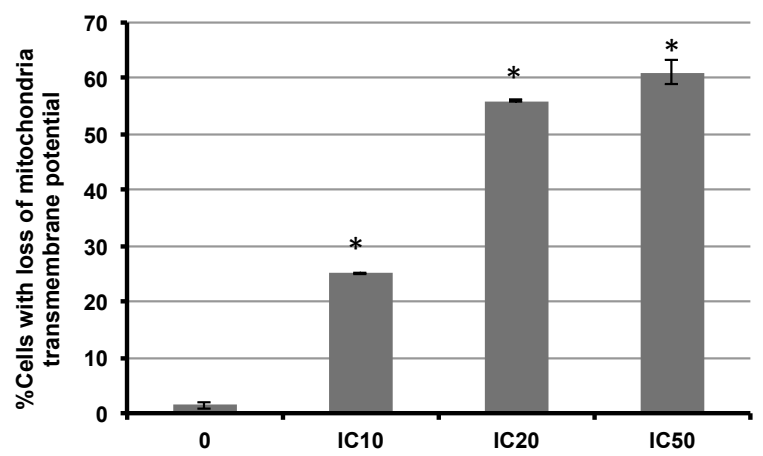

Figure 5. Reduction of Mitochondrial Transmembrane Potential in Enterocarpam-III-treated HepG2 Cells. Percentage of HepG2 cells with loss of MTP increased dose dependently. *, $\mathrm{p}<0.05$ compared to control

by employing flow cytometry technique and analyzing by CellQuest software (Becton-Dickinson, Franklin Lakes, NJ, USA). Data were depicted as histograms and analyzed for percentage of cells with loss of MTP (Banjerdpongchai et al., 2011).

\section{Statistical analysis}

The data are shown as mean \pm S.D. from three independent experiments performed in triplicate. The data were analyzed by one way ANOVA and two groups of experiments were compared with significant value of $\mathrm{p}<0.05$ by Student's t-test.

\section{Results and Discussion}

\section{Cytotoxicity of enterocarpam-III}

Enterocarpam-III was cytotoxic to both HepG2 and MDA-MB-231 cells but less toxic to normal murine fibroblasts with the $\mathrm{IC}_{50}$ of $26.0 \pm 4.45,51.3 \pm 2.05$ and $81.3 \pm 10.1 \mu \mathrm{M}$, respectively. Enterocarpam-III inhibited both cancer cell lines and normal fibroblast cell growth dose dependently as shown in Figure 2. The sensitivity of the cells towards the compound was as follows: HepG2 $>$ MDA-MB-231 > NIH3T3 cells as determined by $\mathrm{IC}_{50}$ levels shown in Figure 2.

\section{Production of reactive oxygen species (ROS)}

ROS production was reduced when concentrations of the compound increased (Figure 3), suggesting the antioxidant property of the enterocarpam-III or the cytotoxic effect or apoptosis-inducing response towards the compound of the HepG2 cells leading to the smaller amount of healthy viable cells left.

\section{Caspase-9, -8 and -3 activities}

After HepG2 cells were treated with various concentrations of enterocarpam-III for $24 \mathrm{~h}$, caspase- 9 and -3 activities were increased, especially at the concentrations of $\mathrm{IC}_{50}$ (Figure $4 \mathrm{~A}, 4 \mathrm{C}$ ), whereas the caspase- 8 activity did not change. It suggests that enterocarpam-III induced HepG2 apoptosis via mitochondrial or intrinsic pathway with the activation of caspase- 9 activity (Alfredsson et al., 2014).
Mitochondrial transmembrane potential (MTP) Reduction

To confirm the involvement of mitochondria, HepG2 cells after incubation with various concentrations of enterocarpam-III for $24 \mathrm{~h}$, the cells were stained with $\mathrm{DiOC}_{6}$ and determined for MTP by using flow cytometry technique. The $\mathrm{DiOC}_{6}$ dye is a cationic fluorochrome that can permeate into intermembranous mitochondrial space and accumulates in the mitochondria in live healthy cells. But in apoptotic cells, the ionic fluorochrome leaks and MTP decreases significantly (Saleh et al., 2014). Percentage of cells with the loss of MTP significantly increased in a concentration-dependent manner (Figure 5).

The increased caspase- 3 activity confirmed the apoptotic cell death mode occurred in HepG2 cells when induced by enterocarpam-III (Figure 4C). The mechanism of enterocarpam-III-induced HepG2 cell apoptosis involved the intrinsic pathway (as due to increased caspase- 9 activity and loss of mitochondrial transmembrane potential) without activation of extrinsic pathway (due to no significant alteration of caspase-8 activity).

From Orophea enterocarpa, stigmalactam is also reported to be another active compound by our group and acts as an anticancer agent with the apoptosisinducing effect on HepG2 cells via intrinsic pathway (Banjerdpongchai et al., 2014). Hence, enterocarpamIII and stigmalactam (Banjerdpongchai et al., 2014), two active compounds from this plant, were proved to be able to inhibit human liver and breast cancer cell proliferation and eventually cause apoptotic cell death via mitochondrial pathway and the induction of caspase-9.

Enterocarpam-III, a natural alkaloid, can be of a high potential and can play a pivotal role as anticancer agent, which will improve the patients' quality of life and efficiency of cancer treatment by using alone or together with the conventional chemotherapy to lessen the side effects. This finding may also increase the economic cost of Orophea enterocarpa, the Thai medicinal plant. The toxicity of the compounds towards animals and human beings should also be investigated before application. The scientists and medical doctors may consider both enterocarpam-III and stigmalactam for further study of their significant roles as anticancer drugs both in animal models, in normal human-beings and finally in clinical trials to be approved and used for cancer treatment.

In conclusion, enterocarpam-III inhibited both human liver HepG2 and breast MDA-MB-231 cell viability and induced HepG2 cells to undergo apoptosis via the intrinsic pathway by induction of caspase- 9 and -3 activities with the loss of MTP. Meanwhile there was no significant alteration in the caspase- 8 activity, indicating the absence of death receptor pathway involvement. This is the first report of enterocarpam-III molecular mechanism in inducing human liver cancer apoptotic death via the intrinsic pathway. Human hepatocellular HepG2 cell line, which is an important in vitro model, can represent as a human cancer disease of in vivo hepatoma, a leading cause of cancer death worldwide and in Thailand. Either is an MDA-MB-231 cell model as human breast cancer, which is also an important cause of mortality and morbidity in women. 


\section{Acknowledgements}

The authors thank Faculty of Medicine Research Fund, Chiang Mai University, Grant No. 016/2557; National Research Council of Thailand (NRCT), Thailand Research Fund (TRF) and the Commission of Higher Education (CHE), Grant No. RMU5080003 for the financial support.

\section{References}

Alfredsson CF, Ding M, Liang QL, et al (2014). Ellagic acid induces a dose- and time-dependent depolarization of mitochondria and activation of caspase- 9 and -3 in human neuroblastoma cells. Biomed Pharmacother, 68, 129-35.

Banjerdpongchai R, Khaw-On P, Ristee C, Pompimon W (2013a). 6,8-Dihydroxy-7-methoxy-1-methyl-azafluorenone induces caspase-8- and -9-mediated apoptosis in human cancer cells . Asian Pac J Cancer Prev. 14, 2637-41.

Banjerdpongchai R, Punyati P, Nakrob A, et al (2011). 4'-Hydroxycinnamaldehyde from Alpinia galanga (Linn.) induces human leukemic cell apoptosis via mitochondrial and endoplasmic reticulum stress pathways. Asian Pac J Cancer Prev, 12, 593-8.

Banjerdpongchai R, Wudtiwai B, Pompimon W (2014). Stigmalactam from Orophea enterocarpa induces human cancer cell apoptosis via a mitochondrial pathway. Asian Pac J Cancer Prev, 15, 10397-400.

Banjerdpongchai R, Wudtiwai B, Sringarm K (2013b). Cytotoxic and apoptotic-inducing effects of purple rice extracts and chemotherapeutic drugs on human cancer cell lines. Asian Pac J Cancer Prev, 14, 6541-8.

Ganguly T, Khar A (2002). Induction of apoptosis in a human erythroleukemic cell line K562 by tylophora alkaloids involves release of cytochrome $\mathrm{c}$ and activation of caspase 3. Phytomedicine, 9, 288-95.

Ji L, Chen Y, Liu T, Wang Z (2008). Involvement of Bcl-xL degradation and mitochondrial-mediated apoptotic pathway in pyrrolizidine alkaloids-induced apoptosis in hepatocytes. Toxicol Appl Pharmacol, 231, 393-400.

Kamaliah M, Kai CC, Myung HP, et al (1986). Aristolactams of Orophea enterocarpa. Phytochemistry, 25, 965-7.

Nayyatip S, Thaichana P, Buayairaksa M, et al (2012). Aristolactam-type alkaloids from Orophea enterocarpa and their cytotoxicities. Int J Mol Sci, 13, 5010-8.

Saleh AM, Aljada A, Rizvi SA, et al (2014). In vitro cytotoxicity of Artemisia vulgaris L. essential oil is mediated by a mitochondria-dependent apoptosis in HL-60 leukemic cell line. BMC Complement Altern Med, 14, 226.

Uadkla O, Yodkeeree S, Buayairaksa M, et al (2013). Antiproliferative effect of alkaloids via cell cycle arrest from Pseuduvaria rugosa. Pharm Biol, 51, 400-4.

Wudtiwai B, Sripanidkulchai B, Kongtawelert P,Banjerdpongchai $R$ (2011). Methoxyflavone derivatives modulate the effect of TRAIL-induced apoptosis in human leukemic cell lines. $J$ Hematol Oncol, 4, 52.

Zhuang WJ, Fong CC, Cao J, et al (2004). Involvement of NF-kappaB and c-myc signaling pathways in the apoptosis of HL-60 cells induced by alkaloids of Tripterygium hypoglaucum (levl.) Hutch. Phytomedicine, 11, 295-302. 